\title{
A PARADIGM SHIFT IN HIGHER EDUCATION TEACHERS’ TEACHING STYLE
}

\author{
Rita Mičiulienè \\ Vytautas Magnus University, Lithuania \\ Nijolė Čiučiulkienẻ \\ Vytautas Magnus University, Lithuania
}

\begin{abstract}
The shift in the educational paradigms, changing the conceptual foundations of studies, forces us to take a closer look at the ability of Lithuanian higher education teachers to establish in practice the new education paradigm modelled on the theoretical foundations of the reform. The study investigates the teaching styles of higher education teachers (N 297) in four universities of applied sciences and the correlation between teachers' teaching style, demographic factors and self-assessed didactic competence. The study findings led to the conclusions highlighting the following statements: although there is no prevailing teaching style, most college teachers work employing the interaction paradigm. The results also indicated that women show more support to learning paradigm than men; young teachers (2535 years old) having assistant positions prefer the teaching paradigm more than teachers of other age and position groups; the representatives of technological sciences are more inclined to the teaching paradigm, while humanities - to interaction paradigm; the teachers who assess their didactic competence highly follow the interaction paradigm in their teacher-student relationship, and low - the teaching paradigm. Though the findings of this study allow capturing a larger shift towards the interaction paradigm, teacher continuing development programmes and support are necessary for higher education teachers. The further research is needed to deepen and extend the findings of this study as well.
\end{abstract}

Keywords: college teacher, didactic competence; educational paradigm, teaching style.

\section{Introduction}

Lithuanian education reform marked the transition in the pedagogical system from traditional to open humanistic education (Targamazdè, 2010; Bruzgelevičiene, 2008). In current practice, this means changes in didactic competence giving up the behaviorist tradition of teaching and taking on the constructivist view of learning. Herein, the didactic competence is perceivied as the interrelated components of a teacher's approach to teaching/learning processes, teaching/learning goals, methods, the student's role, and a teacher's work style. In this study, the teacher's work style, as one of the didactic components, is examined in more detail since "the behavior of the teacher 
probably influences the character of the learning climate more than any other single factor" (Knowles, 1970 cit. in Yoshida, Conti, Yamauchi, \& Iwasaki, 2014).

A limited amount of empirical research on education paradigm shift and teaching style transformations has been conducted in the country during the last decade. Teachers' ability to consolidate the new didactic approach in practice in general education was revealed in 2005 (Jucevičienè, Simonaitiené, Bankauskienè, \& Šiaučiukènienè, 2005). In higher education, a few studies focused on educational paradigm context as a prerequisite for the assessment of students' learning (Morkūnienè \& Jucevičienè, 2010), and the university teachers' innovative activity when improving study programmes (Jezerskytė \& Janiūnaitè, 2009). The didactic competencies of college faculty were examined from the reflective teaching/learning perspective (Bubnys, 2012). Broader literature review on teaching styles during the paradigm shift yielded mixed results: while learnercentred teaching has been advocated in higher education in recent years, teachercentred teaching styles may be still dominant in active practice (Fang, 2012; Dever \& Karabenick, 2011; Shaari, Yusoff, Ghazali, Osman, \& Dzahir, 2014; Ahmed, 2013; Toyama \& Yamazaki, 2020).

Currently, the need for didactic competence change is determined by the new education approach towards teaching and learning. Therefore, it is essential to explore the prevailing teaching style of college teachers in order to plan actions for teachers' didactic competence improvement.

\section{Literature Review}

In this study, the concept of the educational paradigm is perceived as a framework of key provisions and the ideas which are acknowledged by the pedagogical public and which guide research and practice in a field (Kunanbayeva, 2016). In other words, different perceptions of the pedagogical object - conception and a goal of education, an understanding of human growth and development, teacher role, and didactics in the classroom - presupposes different educational paradigms. One of the most important influences on paradigms is one's worldview, a set of constructed perceptions and ideas about reality (Huitt, 2019). According to Yoshida et al. (2014), teachers enter the teaching-learning transaction with a definite set of values, and these in turn influence the teacher's beliefs about the nature of the learner, the purpose of the curriculum, and the role of the teacher in the classroom.

The roles a teacher plays in the classroom, the relationship between teacher and students is defined as a teaching style. Different researchers use relatively different definitions of teaching style, emphasising inclination or even a custom that is used to convey information and skills in the classroom (Shaari et al., 2014), or carrying out instruction or organizing learning or the classroom environment 
(Behar-Horenstein et al., 2006). In any cases, personal behavior is stressed when it comes to knowledge and information transfer (Alhussain, 2012).

When classifying educational paradigms with respect to teaching style, as part of the didactic process, researchers use teaching, learning, and interaction paradigms (Bruzgelevičienè, 2008). Each paradigm on its own way governs practices of education.

The teaching paradigm, which is derived from the behaviourist and social learning tradition (Huitt, 2019), means a process of conveying facts, abilities, memorizing and repeating them. Only the educator knows the purpose of teaching and acts according to it, because s/he is responsible for what the students will learn. Therefore, the teacher-centred teaching style means that the teacher is the expert and authority in presenting information (Alhussain, 2012). This style of instruction is formal, controlled, and autocratic in which the instructor directs how, what, and when students learn (Liu et al., 2006) and the students are considered as passive learners who must learn what to think. The teacher-centred style of instruction is viewed as a more traditional lecture style of teaching: the knowledgeable transmitting knowledge to the novice (Prescott, 2014).

At the centre of the learning paradigm, rooted in connectivism and social cognition (Huitt, 2019), is the student with his/her experience; the emphasis is placed on creating the most effective learning environments possible. Learnercentered teaching style involves the students having a high level of choice, being active in their learning, and having control of the learning. Relying on the literature about teaching styles, Liu et al. (2006) define learner-centered teaching style as a style of instruction that is responsive, collaborative, problem-centered, and democratic, in which both students and the instructor decide how, what, and when learning occurs. This style of teaching encompasses self-directed learning, which can take place "anywhere, anytime" and is very important for students nowadays. Prescott (2014) argues, that teachers who support self-directed learning allow students to acquire subject and strategy knowledge to complete the task independently. Liu et al. (2006) explain that, in learner-centered approaches, the construction of knowledge is shared, and learning is achieved through learners' engagement with various activities. So, the teacher's role within this paradigm is viewed as more of a facilitator rather than a presenter of knowledge (Prescott, 2014; Alhussain, 2012). In a broader sense of education, the idea of focusing on the learner rather than the teacher requires that teachers' and learners' roles be re-examined in the learning process (Liu et al., 2006, p.78).

The interaction paradigm, based on social and cognitive constructivist approaches to teaching and learning (Huitt, 2019) plays an intermediary role between teaching and learning paradigms. Its main idea is that effective learning requires interaction, cooperation and active construction of new knowledge and meanings. This approach can be described as "the student must be taught, but it 
should be agreed how to do it” (Morkūnienè, 2010). It means, that the teacher and the student interact with each other and two-way information transfer prevails. In this case, the instructor is not only the information provider, but also the student's supervisor and consultant, as well as the controller. On the other side, learners are not passive recipients of information, they actively construct their knowledge and skills based on the knowledge they already have, both formal and non-formal, by interacting with their environment. Jucevičiene et al. pointed out, that one of the goals of constructivist learning is to create shared meaning and understanding between the organizers of the learning process and the learners or among the learners in their group. Learners and educators work together to explore the links between new information and existing experience, creating a common understanding (Jucevičienė et al., 2005, p. 7-8).

As some authors noted, an awareness of teaching styles may gain a better understanding of how to improve the interactions with students while maintaining all contextual aspects of teaching, how to impact the classroom setting, activities assessment, and teacher/student interactions or to meet students' needs, as well as address any possible areas of weakness (Yoshida et al., 2014; Alhussain, 2012).

\section{Methodology}

The aim of this study was to investigate the didactic competence of higher education teachers, and namely, their teaching style, under the educational paradigm shift. For that, the study addresses the following research questions:

- What educational paradigm and teaching style based on it is entrenched in the practice of higher education teachers?

- What demographic factors, such as gender, age, position, and subject taught, determine higher education teachers' inclination to one or another educational paradigm?

- How is the self-perceived didactic competence related to the paradigmatical teaching style?

The following hypotheses about the prevailing paradigm in teaching style, related to socio-demographical variables were formulated:

1) Women tend to choose interaction and learning paradigms more often than men.

2) University teachers who have a higher position (associate professors) stick to teaching paradigm.

3) Younger teachers (25-35) tend to rely on interaction paradigm.

4) Representatives of the exact sciences prefer teaching paradigm to interaction paradigm, whereas representatives of humanities choose interaction paradigm. 
A self-administered online questionnaire was developed via the platform apklausa.lt. The instrument of the research comprised several parts, including sefassessment of didactic competence, teaching styles according to educational paradigms, and demographical information. Respondents were asked to rate their didactic competence on a ten-point scale (where 1 means "very bad", 10 "excellent”). The statements about teaching style were adapted from Jucevičienè et al. (2005) study taking into account the specificities of higher education. The statements consist of 8 items along three paradigms or subscales: 4 items for teaching paradigm (for example, "A good teacher is strict and demanding, does not change his opinion according to the students' wishes”), 2 items for learning paradigm (for example, "Students' wishes, suggestions, requests are guidelines for planning and improving the teacher's activities") and 2 items for interaction paradigm (for example, "A teacher only conveys knowledge of the subject, and the student is responsible for his/her own learning and results"). Participants were asked to indicate the extent they agreed/disagreed to these statements measured on a 5 -point Likert scale from $1=$ strongly disagree to $5=$ strongly agree. The Cronbach's alpha value indicated good internal consistency of the statements on the teaching (.781), satisfactory - on interaction (.629) and law - on learning (.586) subscales.

The target population in this study were lecturers of Lithuanian universities of applied sciences (colleges). A total of 297 lecturers from four Lithuanian higher education institutions participated in the survey. The demographic characteristics of the sample are presented in Table 1.

Table 1 Demographic Variables of Participants

\begin{tabular}{llc}
\hline & Variable & $\mathbf{N}$ \\
\hline \multirow{2}{*}{ Gender } & Male & 68 \\
\cline { 2 - 3 } Age & Female & 229 \\
\hline \multirow{2}{*}{ Position } & 25-35 years & 24 \\
\cline { 2 - 3 } & 36-46 years & 177 \\
\cline { 2 - 3 } & 47-57 years & 71 \\
\hline \multirow{4}{*}{$\begin{array}{l}\text { Field of scars and more } \\
\text { subject }\end{array}$} & Associate Professor & 25 \\
\cline { 2 - 3 } & Lecturer & 73 \\
\cline { 2 - 3 } & Assistant & 207 \\
\cline { 2 - 3 } & Natural sciences & 17 \\
\cline { 2 - 3 } & Technological sciences & 29 \\
\cline { 2 - 3 } & Medical and health sciences & 84 \\
\cline { 2 - 3 } & Agricultural sciences & 35 \\
\cline { 2 - 3 } & Social sciences & 118 \\
\cline { 2 - 3 } & Humanitarian sciences & 26 \\
\hline
\end{tabular}


The research data were processed using SPSS 22.0. Descriptive statistics were used to analyse the demographic characteristics of the participants and the scores of their teaching styles in respect of paradigms. Then, the non-parametric tests of Mann-Whitney U (for two unrelated samples) and Kruskal-Wallis (for few unrelated samples) were applied to find differences between groups in relation to gender, age, a position held, and teaching subject.

\section{Results}

For descriptive statistics of the statements that belong to different paradigms, the 5-point scale was transformed into 3-points by combining two adjacent values (for example, "strongly disagree" and "disagree" were merged into "disagree"). Based on the results in Table 2, the interaction paradigmatic statements have the highest mean scores while statements belonging to the teaching paradigm - the lowest ones.

Table 2 The Descriptive Statistics of the Paradigmatical Statements

\begin{tabular}{|c|c|c|c|c|c|}
\hline Statement & $\mathrm{N}$ & Mean & SD & $\begin{array}{c}\% \text { of } \\
\text { disagreement }\end{array}$ & $\begin{array}{c}\% \text { of } \\
\text { agreement }\end{array}$ \\
\hline $\begin{array}{l}\text { Students' wishes, suggestions, requests are } \\
\text { guidelines for planning and improving the } \\
\text { teacher's activities }\end{array}$ & 297 & 3.96 & .763 & 5.4 & 89.5 \\
\hline $\begin{array}{l}\text { The teacher and the student work together } \\
\text { to develop, discuss and follow their own } \\
\text { rules for coexistence and learning }\end{array}$ & 297 & 3.98 & .988 & 7.4 & 79.1 \\
\hline $\begin{array}{l}\text { The teacher, who do not makes a } \\
\text { compromise with students and who knows } \\
\text { his/her value and place, has always been } \\
\text { and will be respected }\end{array}$ & 297 & 3.05 & 1.207 & 47.2 & 50.9 \\
\hline $\begin{array}{l}\text { The teacher transfers the knowlege of the } \\
\text { subject taught and the student is } \\
\text { responsible for his/her own learning }\end{array}$ & 297 & 3.43 & 1.364 & 36.4 & 56.6 \\
\hline $\begin{array}{l}\text { The student applies to the teacher only } \\
\text { when s/he encounters an insurmountable } \\
\text { problem or to discuss the obtained results }\end{array}$ & 297 & 3.12 & 1.316 & 41.1 & 49.1 \\
\hline $\begin{array}{l}\text { The teacher formulates the tasks and } \\
\text { requirements while the student carries out. } \\
\text { It's a time-proven relationship }\end{array}$ & 297 & 2.65 & 1.039 & 49.5 & 25.9 \\
\hline $\begin{array}{l}\text { A good teacher is strict and demanding, } \\
\text { without changing his opinion according to } \\
\text { the wishes of the students }\end{array}$ & 297 & 2.22 & 1.106 & 70.1 & 24.6 \\
\hline $\begin{array}{l}\text { The student should always feel a slight } \\
\text { fear when interacting with the teacher. } \\
\text { That promotes respect and attitudes to } \\
\text { learning }\end{array}$ & 297 & 1.67 & 0.758 & 87.2 & 2.4 \\
\hline
\end{tabular}


SOCIETY. INTEGRATION. EDUCATION

Proceedings of the International Scientific Conference. Volume I, May $28^{\text {th }}-29^{\text {th }}$, 2021. 442-453

Further, 8 statements were transformed into three groups of teaching styles and differences among these groups were analysed. The results are presented in tables 3-6. The statistical differences were found between men and women (Table 3): male teachers significantly more than female teachers were inclined to teaching and interaction styles of work. Female participants supported the learnercentred style (learning paradigm) in the teacher-student relationship significantly more than males. Thus, it is possible to state, that the first hypothesis is only partially proved, as men support interaction paradigm more than women.

Table 3 The Teaching Style of College Teachers by Gender

\begin{tabular}{|c|c|c|c|c|c|}
\hline Paradigm & Gender & $\mathrm{N}$ & Mean Rank & Mann-Whitney U Test & $\mathrm{p}$ \\
\hline \multirow[t]{2}{*}{ Teaching } & Female & 229 & 142.06 & \multirow{2}{*}{6197.500} & \multirow{2}{*}{$<.01$} \\
\hline & Male & 68 & 172.36 & & \\
\hline \multirow[t]{2}{*}{ Interaction } & Female & 229 & 141.49 & \multirow{2}{*}{6065.500} & \multirow{2}{*}{$<.05$} \\
\hline & Male & 68 & 174.30 & & \\
\hline \multirow[t]{2}{*}{ Learning } & Female & 229 & 155.24 & \multirow{2}{*}{6356.500} & \multirow{2}{*}{$<.05$} \\
\hline & $\overline{\text { Male }}$ & 68 & 127.98 & & \\
\hline
\end{tabular}

The results in Table 4 suggest that assistants, who are the youngest and the lowest category of university teachers, accepted the statements belonging to the teaching paradigm, thus the second hypothesis has not been proved. Concerning the remaining two paradigms, no statistically significant differences were found.

Table 4 The Teaching Style of College Teachers According to the Position

\begin{tabular}{|c|c|c|c|c|c|}
\hline Paradigm & Position & $\mathrm{N}$ & Mean Rank & Kruskal Wallis Test & $\mathrm{p}$ \\
\hline \multirow{3}{*}{ Teaching } & Assoc. prof. & 73 & 179.82 & \multirow{3}{*}{21.622} & \multirow{3}{*}{$<.001$} \\
\hline & Lecturer & 207 & 134.06 & & \\
\hline & Assistant & 17 & 198.62 & & \\
\hline \multirow{3}{*}{ Interaction } & Assoc. prof. & 73 & 166.51 & \multirow{3}{*}{5.930} & \multirow{3}{*}{$>.05$} \\
\hline & Lecturer & 207 & 145.14 & & \\
\hline & Assistant & 17 & 120.82 & & \\
\hline \multirow{3}{*}{ Learning } & Assoc. prof. & 73 & 148.16 & \multirow{3}{*}{1.676} & \multirow{3}{*}{$>.05$} \\
\hline & Lecturer & 207 & 151.35 & & \\
\hline & Assistant & 17 & 123.82 & & \\
\hline
\end{tabular}

The statistical differences were found among the age groups (Table 5). The youngest teachers (25-35 years) statistically more agreed with the teaching and with the learning paradigms' statements, while the teachers between 36 and 46 years old - with the interaction paradigm statements. The third hypothesis was rejected. 
Mičiulienè \& Čiučiulkienè, 2021. A Paradigm Shift in Higher Education Teachers’ Teaching Style

Table 5 The Teaching Style of College Teachers by Age

\begin{tabular}{|c|c|c|c|c|c|}
\hline Paradigm & Age & $\mathrm{N}$ & Mean Rank & Kruskal Wallis Test & $\mathrm{p}$ \\
\hline \multirow{4}{*}{ Teaching } & 25-35 years & 24 & 219.31 & \multirow{4}{*}{28.418} & \multirow{4}{*}{$<.001$} \\
\hline & 36-46 years & 177 & 151.06 & & \\
\hline & 47-57 years & 71 & 114.68 & & \\
\hline & 58 and more & 25 & 163.52 & & \\
\hline \multirow{4}{*}{ Interaction } & 25-35 years & 24 & 108.77 & \multirow{4}{*}{11.564} & \multirow{4}{*}{$<.01$} \\
\hline & 36-46 years & 177 & 159.83 & & \\
\hline & $47-57$ years & 71 & 144.14 & & \\
\hline & 58 and more & 25 & 124.76 & & \\
\hline \multirow{4}{*}{ Learning } & 25-35 years & 24 & 231.46 & \multirow{4}{*}{53.737} & \multirow{4}{*}{$<.001$} \\
\hline & 36-46 years & 177 & 161.77 & & \\
\hline & 47-57 years & 71 & 100.56 & & \\
\hline & 58 and more & 25 & 117.00 & & \\
\hline
\end{tabular}

The field of science, in which the subject is taught, had a significant effect on participants' attitudes concerning the teaching style (Table 6). The research findings proved the fourth hypothesis. The representatives of technological sciences statistically preferred teaching paradigm, and the representatives of agricultural and humanitarian sciences - interaction paradigm, while no statistical differences were found in the learning paradigm.

Table 6 The Teaching Style of College Teachers by Subject Taught

\begin{tabular}{|c|c|c|c|c|c|}
\hline Paradigm & Field of science & $\mathrm{N}$ & Mean Rank & Kruskal Wallis Test & $\mathrm{p}$ \\
\hline \multirow{6}{*}{$\begin{array}{c}\text { Teachin } \\
\text { g }\end{array}$} & Natural sciences & 29 & 52.03 & \multirow{6}{*}{109.015} & \multirow{6}{*}{$<.001$} \\
\hline & Technological sciences & 84 & 220.48 & & \\
\hline & Medical and health scien & 35 & 130.04 & & \\
\hline & Agricultural sciences & 5 & 159.00 & & \\
\hline & Social sciences & 118 & 138.13 & & \\
\hline & Humanitarian sciences & 26 & 99.15 & & \\
\hline \multirow{6}{*}{$\begin{array}{c}\text { Interacti } \\
\text { on }\end{array}$} & Natural sciences & 29 & 55.95 & \multirow{6}{*}{91.263} & \multirow{6}{*}{$<.001$} \\
\hline & Technological sciences & 84 & 131.48 & & \\
\hline & Medical and health scien & 35 & 110.29 & & \\
\hline & Agricultural sciences & 5 & 254.90 & & \\
\hline & Social sciences & 118 & 175.80 & & \\
\hline & Humanitarian sciences & 26 & 219.52 & & \\
\hline \multirow{6}{*}{$\begin{array}{c}\text { Learnin } \\
\mathrm{g}\end{array}$} & Natural sciences & 29 & 154.14 & \multirow{6}{*}{5.699} & \multirow{6}{*}{$>.05$} \\
\hline & Technological sciences & 84 & 139.58 & & \\
\hline & Medical and health scien & 35 & 135.87 & & \\
\hline & Agricultural sciences & 5 & 197.40 & & \\
\hline & Social sciences & 118 & 158.81 & & \\
\hline & Humanitarian sciences & 26 & 137.52 & & \\
\hline
\end{tabular}


The participants assessed their didactic competence high enough $(\mathrm{M}=7.97$; $\mathrm{SD}=1.43$ ). The statistically significant differences were found between two groups: the college teachers, who assessed their didactic competence as satisfactory (3-4 grades), were more inclined into teaching paradigm (KruskalWallis test $=36.368, \mathrm{p}<.001$ ) and those, who assessed their didactic competence very good (9-10 grades), were more inclined into interaction paradigm (KruskalWallis test=17.746, $\mathrm{p}<.001)$.

\section{Discussion and Conclusions}

The findings of this study highlight that there is no clear dominant teaching style, most college teachers work sticking to an interaction paradigm. Compared to the similar study of secondary school teachers which was carried out in 2005, the university teachers of 2020 demonstrate greater acceptance of interaction paradigm. A previous study found that secondary school teachers were largely driven by impact (or teaching) paradigm, less often - by interaction paradigm, and there were no traits of a learning paradigm-based teaching style (Jucevičienè et al., 2005, p.2). Although this study examined teachers of applied universities, an overall assessment of the national context may indicate a larger shift towards the paradigm of interaction. Previous research performed in other countries suggests that instructors still use traditional, teacher-centered styles in university settings and the learner-centered approach is not widely practiced in higher education (Liu et al., 2006). Still, recent research findings demonstrate a variety of styles (Alhussain, 2012) or the tendency of learner-centered teaching preference rather than teacher-centered teaching (Prescott, 2014). In Lithuania the findings of a study performed in 2012 underline the fact that the reflective practice of applied university teachers might be assessed as sufficient, at the same time there was revealed the weak areas of teaching activity based on the interaction paradigm (Bubnys, 2012).

The statement that there is no dominant paradigm is based on the following arguments. Firstly, the descriptive statistics revealed a preference for the interaction paradigm, and diminishing support for the teaching paradigm statements. Meanwhile, statistically significant differences between groups indicate preferences for both interaction and teaching paradigms, and no statistically significant differences were found between groups concerning the learning paradigm, in terms of subject occupation, subject taught. Secondly, although statistically significant differences were found between the groups, some groups have high acceptance of all paradigm statements, for example, the mean rank of agricultural sciences is high for all paradigm statements, and young teachers (25-35 years old) have a high mean rank for opposite teaching and learning paradigms. This might indicate that the statements describing the 
different paradigms were not so well understood by the respondents. Therefore, the study should be repeated with more accurate paradigm descriptions and a larger sample. The correlation of paradigm statements with the sociodemographic characteristics of college teachers revealed that teaching style significantly depends on such demographic variables as gender, age, position, subject taught. A learner-centered teaching style is more acceptable for women than for men, where the teacher is more a facilitator of the learning process. Similar findings were found in Nelson Laird et al. (2007) study: women tend toward active and interactive learning environment that are associated with a learner-centered approach, to a greater degree than men.

Quite unexpected was to find that young teachers (25-35 years old) and assistants (age and position are often related) follow the teaching paradigm more in their practice than teachers in other age groups. Perhaps it can be hypothetically stated that the teaching paradigm and teacher-centered teaching style are more "convenient" for young teachers who lack experience. The next age group of teachers (36-46 years old) is most inclined to support the beginnings of interaction. Somewhat surprising is such a sharp turn in approaches over a relatively small age difference. We have not found similar studies that could confirm or refute our insights or explain such "twists and turns" of attitudes. Therefore, we would think that further and deeper research might be perspective in this direction.

It is known that different fields of science have different worldviews. This is also demonstrated by our study findings. The distinctive tendency of the representatives of technological sciences is to rely on the teaching paradigm, the humanities on their turn prefer the interaction paradigm. These tendencies can be explained by the natural differences of these sciences: the technological sciences focus more on order, rules, strict, clear structures, and the humanities rely on communication, understanding, and value. Belonging to a field of science also presupposes certain patterns of behaviour and interaction in the classroom.

A correlation was found between self-assessment of didactic competence and teaching paradigm/style: teachers who value personal didactic competence highly follow the interaction paradigm in their work, and those who think that their didactic competence is low prefer the teaching paradigm. This suggests that we need more teacher training and support programs in higher education to facilitate change in teachers' didactic practice.

\section{Acknowledgments}

This study is a part of a wider research. The authors would like to thank Lauryna Gružaite for her contribution to data collection. 
SOCIETY. INTEGRATION. EDUCATION

Proceedings of the International Scientific Conference. Volume I, May $28^{\text {th }}-29^{\text {th }}, 2021.442-453$

\section{References}

Ahmed, A. K. (2013). Teacher-centered versus learner-centered teaching style. Journal of Global Business Management, 9(1), 22. Retrieved from https://search.proquest.com/ openview/cf1884e9203c3cfc877c34a0de33dc8b/1.pdf?pqorigsite $=$ gscholar\&cbl $=406316$

Alhussain, A. M. (2012). Identifying Teaching Style: The Case of Saudi College English Language and Literature Teachers. English Language Teaching, 5(8), 122-129. DOI:10.5539/elt.v5n8p122

Behar-Horenstein, L. S., Mitchell, G. S., Notzer, N., Penfield, R., \& Eli, I. (2006). Teaching style beliefs among US and Israeli faculty. Journal of Dental Education, 70(8), 851-856. Retrieved from https://onlinelibrary.wiley.com/doi/epdf/10.1002/j.0022-0337. 2006.70.8.tb04151.x

Bruzgelevičienè, R. (2008). Ugdymo paradigmų kaitos permanentiškumo problema: teorijapraktinè veikla-mokytoju rengimas $=$ The problem of permanence in the shift of educational paradigms: theory-practice-teacher training. Mokytoju ugdymas, (10), 74-90. ISSN 1822-119X.

Bubnys, R. (2012). Kolegijos dėstytojų didaktinè kompetencija reflektyvaus mokymo (si) kontekste. Profesinés studijos: teorija ir praktika, (10), 26-33. ISSN 1822-3648.

Dever, B. V., \& Karabenick, S. A. (2011). Is authoritative teaching beneficial for all students? A multi-level model of the effects of teaching style on interest and achievement. School Psychology Quarterly, 26(2), 131-144. https://doi.org/10.1037/a0022985

Fang, S. U. N. (2012). A survey of teacher-student style mismatches. Higher Education of Social Science, 3(1), 5-12. http://dx.doi.org/10.3968/j.hess.1927024020120301.1036

Huitt, W. (2019, August). Analyzing paradigms used in education and schooling. Educational Psychology Interactive. Atlanta, GA. Retrieved from http://www.edpsycinteractive.org/ topics/intro/analyzing-paradigms.pdf

Yoshida, F., Conti, G. J., Yamauchi, T., \& Iwasaki, T. (2014). Development of an Instrument to Measure Teaching Style in Japan: The Teaching Style Assessment Scale. Journal of Adult Education, 43(1), 11-18. https://files.eric.ed.gov/fulltext/EJ1047371.pdf

Jezerskytė, E., \& Janiūnaitè, B. (2009). Dėstytojo inovacinės veiklos bruožai tobulinant studijų programas: besikeičiančios edukacinès paradigmos kontekstas. Jaunuju mokslininku darbai, 1(22), 73-82. ISSN 1648-8776

Jucevičienė, P., Simonaitienè, B., Bankauskienė, N., \& Šiaučiukėnienė, L. (2005). Mokytoju didaktinès kompetencijos atitiktis šiuolaikiniams švietimo reikalavimams. Tyrimo ataskaita. Kaunas: KTU.

Kunanbayeva, S. S. (2016). Educational Paradigm: Implementation of the Competence-Based Approach to the Higher School System. International Journal of Environmental and Science Education, 11(18), 12699-12710. Retrieved from https://files.eric.ed.gov/ fulltext/EJ1126626.pdf

Liu, R., Qiao, X. \& Liu, Y. (2006). A Paradigm Shift of Learned-centred Teaching Style: Reality or Illusion? Arizona Working Papers in SLAT, Vo.13. University of Arizona. Retrieved from https://journals.uair.arizona.edu/index.php/AZSLAT/article/view/21276/20856

Morkūnienè, V., \& Jucevičienè, P. (2010). Studentų mokymosi, grịsto skirtinga edukacine paradigma, rezultatu vertinimo ypatumai. Baltic Journal of Sport and Health Sciences, 3(78).

Nelson Laird, T. F., Garver, A. K., \& Niskodé, A. S. (2007). Gender gaps: Understanding teaching style differences between men and women. Association for Institutional 
Mičiulienè \& Čiučiulkienè, 2021. A Paradigm Shift in Higher Education Teachers’ Teaching Style

Research Annual Forum. Retrieved from http://cpr.indiana.edu/uploads/ 2007airgendergaps.pdf

Prescott, J. (2014). Teaching style and attitudes towards Facebook as an educational tool. Active Learning in Higher Education, 15(2), 117-128. https://doi.org/10.1177/1469787 414527392

Shaari, A. S., Yusoff, N. M., Ghazali, I. M., Osman, R. H., \& Dzahir, N. F. M. (2014). The relationship between lecturers' teaching style and students' academic engagement. Procedia-Social and Behavioral Sciences, 118, 10-20. https://doi.org/ 10.1016/j.sbspro.2014.02.002

Toyama, M., \& Yamazaki, Y. (2020). Are There Effects of a Match between Learning Style and Teaching Style in an EFL Classroom? Innovation in Language Learning and Teaching, 14(3), 243-258. https://doi.org/10.1080/17501229.2019.1575386 